\title{
Analysis on Marxist Ecological Concept and Its Guiding Significance to China's Ecological Civilization Construction
}

\author{
Haipo Pang \\ School of Marxism \\ Chifeng University \\ Chifeng, China 024000
}

\begin{abstract}
The progress of science and technology and advancement of economic integration have quickened the ability of people to transform and use the nature, and the disharmony between man and nature leads to a global ecological crisis. Firstly, this paper deeply reveals the dialectical relationship between man and nature, and then expounds the theory of Marxist ecological concept, finally, discusses the guiding significance of Marxist ecological concept to the ecological civilization construction in China.
\end{abstract}

Keywords-Marxist ecological concept; ecological civilization; guiding significance

\section{INTRODUCTION}

The reports of the 19th National Congress of the Communist Party of China point out: define that the overall layout for the cause of socialism with Chinese characteristics is "Five in One", namely, economic construction, political construction, cultural construction, social construction and ecological civilization construction, moreover, the ecological civilization construction is the foundation. The tremendous progress of science and technology and the global economic integration have not only accelerated people's ability to transform and utilize the natural resources, but also have increased huge material wealth for mankind. However, some ecological and environmental problems have also come along with it. In view of these ecological crises, it is necessary to thoroughly explore the dialectical relationship between man and nature in Marxism and profoundly appreciate the Marxist Ecological Concept, which can guide and help us better execute the scientific outlook on development and construct a harmonious socialist society.

\section{EXPOSITION ON THE MARXIST ECOLOGICAL CONCEPT}

Marx and Engels expounded their ideas on the relationship between man and nature as follows:

\section{A. Exposition on the Relationship between Man and Nature in Marxism}

Firstly, man and nature should be dialectical unify. Human beings belong to nature, and nature provides a material basis for human survival and development. From this, it can be concluded that the relationship between man and nature should be dialectical unity. This shows that living in nature, human beings constantly rely on and influence nature. As Marx said, "as a natural living being, human have natural force and vitality, meanwhile, they are bound and restricted."[1] Human beings come from nature and are finite, and nature is infinite, so human beings should keep gratitude and reverence in heart for nature. As a result, Marx completely disagreed with the statement that "labor is the source of all wealth", and sharply refuted that: "labor is not the source of all wealth and a manifestation of natural force, that is, the manifestation of labor force."[2] Human beings live in nature, and as far as our current surveying level is concerned, we find that the earth is the only planet of suitable for the life. Therefore, human beings should care for nature as much as their own body and share life and death with nature.

Secondly, man and nature are opposite. There are some laws for the development and change of nature. It requires that human beings cannot totally do whatever they want in the course of transforming nature, and must follow the law of nature and do things according to the laws of nature. Marx said: "human plans that violate the law of nature will eventually bring disaster."[3] Engels put forward: "we are always intoxicated with our conquest of nature, and for such a conquest, nature has taught us. For every conquest, we have surely achieved the results we want at the beginning, but later on, many cases appear that we have not thought in advance, which often covers up the results at the beginning. To get some arable land, residents in many parts of the world have cut down large areas of forests, but to their surprise, these places they farmed have become barren land. This is because the residents have deprived these places of large areas of forests, as well as the center of accumulation and storage of water."[4] He further put forward: "the interaction of the dead substances in nature contains harmony and conflict: the interaction of living objects not only contains conscious and unconscious cooperation, but also the 'struggle'.'[5]

\section{B. Marxist Theory on Ecological Relationship}

Firstly, the reconciliation between human and nature must respect the natural law and conduct systematic adjustment. The ecological problem is a great systems engineering, which can 
not be solved by one or two people but the whole society that should pay much attention to it. We need to work together and make efforts. In On the Jewish Question, Marx has put forward that "the view of nature formed by private property and money worship is a great disrespect for nature. In the religion of the Jews, although the nature is recognized, it is only the nature of imagination. From the above significance, Thomas Vencel concluded that the following phenomena can not be accepted: all creatures, including the creatures in water, in sky and in ground that have become property, but creatures should be free." [6] In the early days, the capitalists caused great harm to nature due to paying much attention to material interests. This aggravates the seriousness of the ecological problems and casts a great impact on the interests of the bourgeoisie, which forces the bourgeoisie to take some measures to save their losses. Marx put forward that to meet the interest requirements, the whole capitalist society make the ecological problems become more serious. But in the eastern society, it is impossible to achieve scientific development. He said "The governments of Asia are conducting an economic function, that is, the function of the central government to deal with public works. However, if the central government does not make timely water injection and discharge, it will cause that the engineering facilities gradually are abandoned, and the old land became barren." [7] Because in this production mode, the decisions of government will cause continuous failures due to the lack of democracy, which destroys the environment accordingly, so the social system causes disharmony between man and nature. Therefore, Engels pointed out that "to complete this kind of regulation, it should not only be recognized by human beings, but also need to reform the mode of production and the social system." [8]

Secondly, using scientific and technological means realize the coordinated development of man and nature. Marx believed: modern industrial development "has brought about more advanced industrial and scientific strength in society"; meanwhile, along with the strengthening of human control over nature, everyone gradually becomes the slave of others and their own". Therefore, scientific and technological progress has two sides, and it has caused great harm to nature while creating a large amount of material wealth. To solve this problem, it is still inseparable from the progress of science and technology. Marx said: "producers control nature together and do not let nature control themselves. They constantly ask for various substances from nature for their own use to satisfy their human nature finally." We often say, "garbage is an available and recyclable raw material". Marx had expressed the same idea before that "the so-called waste can exert important role in any industry."[9] Marx took the existing chemical enterprises as example illustration and said "the chemical industry can not only discover the way to use the industrial wastes, but also use other industrial wastes, for example, the coal tar abandoned by people can be transformed into some dyes, and later they can be turned into some medicine.'[10] Therefore, we should apply the research results of science and technology to gradually explore many advanced technological process, mean and method to turn "waste" into wealth.

\section{THE GUIDING SigNIFICANCE OF MARXIST ECOLOGICAL CONCEPT TO THE CONSTRUCTION OF ECOLOGICAL CIVILIZATION IN CHINA}

Marx and Engels proposed the theory of ecology about 160 years ago. However, after one or two hundred years of development, the whole world's problems about nature, ecology and environment have not only been reduced, but also have become more obviously, and so does our country.

\section{A. Establish a New Harmonious Development between Human and Nature and Firmly Set up the Scientific Concept of Development}

Firstly, we must correctly deal with the relationship between man and nature. Nature is the material basis of mankind, and man and nature cannot be separated for a moment. Man is a character in nature, not an onlooker. The relationship between man and nature is not to oppress or be oppressed, much less to abuse and be abused. Human beings should consider nature as a friend and care for and protect nature. Under the premise of respecting the laws of nature, we should rationally develop nature to satisfy our needs.

Secondly, environmental ecological protection is the problem in development model. It is not only involved with the economy, but also inseparable from environmental pollution. In the process of conducting all kinds of works, governments at all levels must take environmental protection as a behavior standard for the inspection of various government departments and related enterprises and institutions, and achieve the scientific development earnestly.

\section{B. Change the Way of Economic Development and Promote Sustainable Development}

Over the years, the economic development in China mainly has adopted the extensive way. This way makes us pay a huge price, and the main manifestations are as follows: immoderately exploit resources and lack recycling and processing for pollutants. This has seriously damaged the ecological balance, thus causing great damage to people's physical and mental health. These phenomena make us clearly realize that we should change the extensive economic development way and develop a circular economy as a substitute, so that the energy and resources can be fully utilized and the development of society, economy and environment can be coordinated.

We have advocated a vigorous development of circular economy. Circular economy is inseparable from sustainable development. It more embodies the coordination, order and coexistence of the whole social organic system and the natural ecosystem, which is system engineering related to the overall and coordinated development of the whole society. The circular economy is not what we have imagined, and does not mean blindly developing the economy, or simply improving technology or paying more attention to environmental protection issues. It takes more consideration about the problems of coordinated development between man and nature, so that our society production is closer to the natural ecosystem. With less value on quantity and more consideration on quality, the whole society will embark on a civilized 
development road with production and development, rich life and sound ecology.

\section{Gradually Improve the Laws and Regulations of Ecological Environmental Protection, and Enhance People's Awareness of Environmental Protection}

The construction of ecological civilization is a long-term project. On the one hand, we should carry out moral constraints and constantly educate people on ecological protection and guide people in public opinion to enhance their consciousness. On the other hand, we should take legal measures to enhance the legal awareness of people on ecological protection. Therefore, the government should really pay attention to this problem, constantly improve the corresponding laws and regulations, strengthen the supervision of environmental protection, enhance law enforcement capability, establish some corresponding compensation measures, and bring the environmental performance into cadre's performance appraisal mechanism as an assessment index.

Everybody is responsible for protecting the environment. On the one hand, in each education stage, we should comprehensively develop awareness education on the harmonious coexistence between man and nature to make everyone to actively participate in this activity. People should constantly learn the knowledge of ecological construction and environmental protection and actively join in the practice. On the other hand, we should make multi-angle propaganda by means of news media, so that the whole society can realize that nature is our beautiful homeland and a guarantee of survival. We should also establish the green values and everyone needs to care for nature and cherish the life. We should carry out the activities of ecological and environmental protection in many ways through the media such as campus, community and so on, and transform the internalization consciousness into the external action, so that the whole society can gradually develop a good atmosphere of respecting nature, loving nature, thanksgiving nature and returning nature.

\section{CONCLUSION}

In general, the construction of ecological civilization is the basis for the construction of a socialist harmonious society, which requires us to do things based on the two principles, namely, the truth principle and the value principle. On the one hand, adhere to the truth principle, follow the laws of nature, and act in accordance with natural laws. Resolutely put an end the behavior that destroys the nature relentlessly for their personal interests regardless of resource conservation and environmental protection. It is necessary to coordinate the relationship between human and society, and human and nature with the sustainable scientific concept of development. On the other hand, insist on the value principle, that is, take the meeting of people's needs as a starting point of action. The existing things in nature that can meet the needs of our lives are limited, and it requires us to continuously transform nature and make better use of nature to serve our lives and social development, which is also related to sustainable development. In the future economic construction, we need to change the way of economic development, develop circular economy, make rational use of resources, and reduce environmental pollution, so as to achieve coordinated development of economy, population, resource and environment. As required by the report of the 19th National Congress of the Communist Party of China: by 2050, we should build our country into a prosperous, democratic, civilized and harmonious modern socialist country.

\section{REFERENCES}

[1] Karl Marx and Frederick Engels Volume 42, People's Publishing House, 1979 Edition, 167-168

[2] Selected Works of Marx and Engels Volume 3, People's Publishing House, 1995 Edition, 5.

[3] Karl Marx and Frederick Engels Volume 42, People's Publishing House 1979 Edition, 95.

[4] Selected Works of Marx and Engels Volume 1, People's Publishing House, 1979 Edition, 517-518.

[5] Engels: Dialectics of Nature, People's Publishing House, 1971 Edition, 625.

[6] Engels: Dialectics of Nature, People's Publishing House, 1971 Edition, 625 .

[7] Marx: Capital Volume 1, People's Publishing House, 1975 Edition, 448-449.

[8] Karl Marx and Frederick Engels Volume 9, People's Publishing House, 1961 Edition, 145-146.

[9] Karl Marx and Frederick Engels Volume 25, People's Publishing House 925-926.

[10] Capital Volume 3, People's Publishing House, 1975 Edition, 118. 